\title{
Global Warming: CO2s, Temperature Rise and Solar Power
}

\author{
Parks \\ Florent Dieterlen ${ }^{1} \&$ Jan-Erik Lane ${ }^{2 *}$ \\ ${ }^{1}$ Independent scholar, Geneva \\ ${ }^{2}$ Fellow with Public Policy Institute, Belgrade; 10 Charles Humbert, 1205 Geneva; 559A, 3rd Floor, \\ Thuya Street, 9th Quarter, Yangon, Myanmar \\ * Jan-Erik Lane, E-mail: janeklane@ gmail.com \\ Received: July 15, 2017 \\ Accepted: July 23, 2017 Online Published: July 26, 2017 \\ doi:10.22158/jepf.v3n3p358 \\ URL: http://dx.doi.org/10.22158/jepf.v3n3p358

\begin{abstract}
For the COP23 reunion of states and international organisations in the fall with islands state Fiji as host holds that the focus must be upon the GOAL II in the COP21 Treaty, namely decarbonisation with 30-40 per cent of 2005 levels until 2030. A few countries now meet the GOAL I of halting the rise in CO2 emissions. And the rest should be asked and helped to do so. But the GOAL II is a very big challenge. It can only be fulfilled with massive investments in solar panel parks.
\end{abstract}

\section{Keywords}

Decarbonisation and the UNFCCC, the COP21 GOALS I, II, III, renewables, global warming dangers, Ouarzazate size solar parks

\section{Introduction}

When physicist Stephen Hawking raises the question of irreversibility of climate change, bringing mankind to the brink of extinction, one needs to stop and reflect: Could this really happen during this century? This crucial question concerns the efficiency of the work of the UNFCCC and its many meetings, like the coming COP23: Is the COP21 Treaty really enough to halt the carbonization of the globe?

In this article, we attempt two things that are highly relevant to Hawking's warning, namely:

a) What is the link between $\mathrm{CO} 2 \mathrm{~s}$ and temperature rise?

b) How could solar power parks promote decarbonisation?

If these two links are known more precisely, policy will be improved both by international governance and in nation policy-making. What remains not fully known is what temperature rise men and women can support: 4 degrees? Or 6 degrees—-hardly! In any case, climate change at those levels will bring about very negative changes for mankind and other living species as well as the overall environment. 


\section{The Base Model: Energy and CO2 Emissions}

To understand the real role that energy plays for the economy and $\mathrm{CO} 2$ :s, we turn to the Kaya model. The basic theoretical effort to model the greenhouse gases, especially $\mathrm{CO} 2 \mathrm{~s}$, in terms of a so-called identity is the deterministic Kaya equation (Kaya \& Yokoburi, 1997).

In theories of climate change, the focus is upon so-called anthropogenic causes of global warming through the release of Greenhouse Gases (GHG). To halt the growth of the GHG:s, of which CO2:s make up about 70 per cent, one must theorize the increase in $\mathrm{CO} 2$ :s over time (longitudinally) and its variation among countries (cross-sectionally). As a matter of fact, $\mathrm{CO} 2$ :s have very strong mundane conditions in human needs and social system prerequisites. Besides the breading of living species, like Homo sapiens for instance, energy consumption plays a major role. As energy is the capacity to do work, it is absolutely vital for the economy in a wide sense, covering both the official and the unofficial sides of the economic system of a country. The best model of carbon emissions to this day is the so-called Kaya model:

(E1) Kaya's identity projects future carbon emissions on changes in Population (in billions), economic activity as GDP per capita (in thousands of $\$ U S(1990) /$ person year), energy intensity in Watt years/dollar, and carbon intensity of energy as Gton $\mathrm{C}$ as $\mathrm{CO}_{2}$ per TeraWatt year (http://www.climatemodels.uchicago.edu/kaya/kaya.doc.html).

Concerning the equation (E1), it may seem premature to speak of a law or identity that explains carbon emissions completely, as if the Kaya identity were a deterministic natural law. It will not explain all the variation, as there is bound to be other factors that impact, at least to some extent. Thus, it is more proper to formulate it as a stochastic law-like proposition, where coefficients will be estimate using various data sets, without any assumption about stable universal parameters. Thus, we have this equation format for the Kaya probabilistic law-like proposition, as follows:

(E2) Multiple Regression: $Y=a+b_{1} X_{1}+b_{2} X_{2}+b_{3} X_{3}+\ldots+b_{t} X_{t}+u$

Note. $\mathrm{Y}=$ the variable that you are trying to predict (dependent variable); $\mathrm{X}=$ the variable that you are using to predict $\mathrm{Y}$ (independent variable); $\mathrm{a}=$ the intercept; $\mathrm{b}=$ the slope; $\mathrm{u}=$ the regression residual. http://www.investopedia.com/terms/r/regression.asp\#ixzz4Mg4Eyugw

Thus, using the Kaya model for empirical research on global warming, the following anthropogenic conditions would affect positively carbon emissions:

(E3) $\mathrm{CO} 2 \mathrm{~s}=\mathrm{F}$ (GDP/capita, Population, Energy intensity, Carbon intensity).

I make an empirical estimation of this probabilistic Kaya model with a longitudinal test for 1990-2014, i.e., World data 1990-2015: (E4) $\mathrm{LnCO} 2=0,62 * \mathrm{LN}$ Population $+1,28 * \operatorname{Ln}(\mathrm{GDP} /$ Capita $)+0,96 *$ $\mathrm{Ln}($ Energy/GDP); R2 $=.90$.

The close link in the Kaya model may be visualized in Figure 1. 


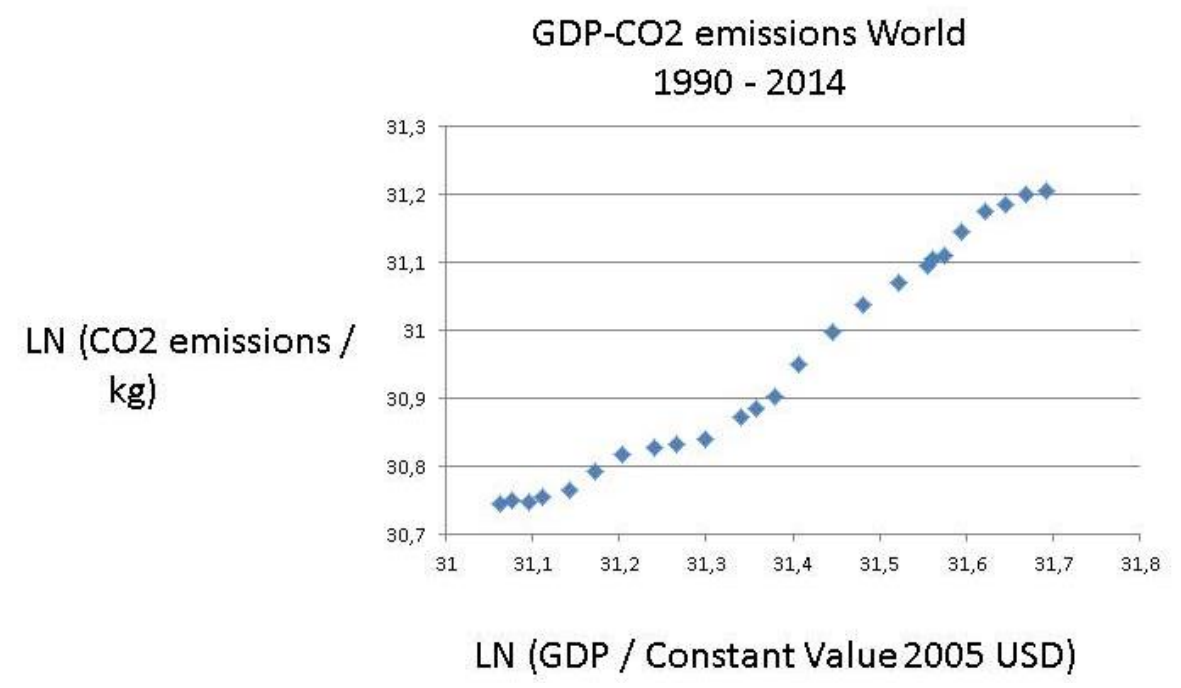

Figure 1. Global GDP-CO2 Link: $y=0,80 x+5,96 ; R^{2}=0,97(N=59)$

The findings show that total GHG:s or CO2:s go with larger total GDP, i.e., GDP per person * population. To make the dilemma of energy versus emissions even worse, we show in Figure 2 that GDP increase with the augmentation of energy per capita. This makes the turn to a sustainable economy (Sachs, 2015) unlikely, as nations plan for much more energy in the coming decades.

GDP vs. Energy usage per capita 1990 - 2014

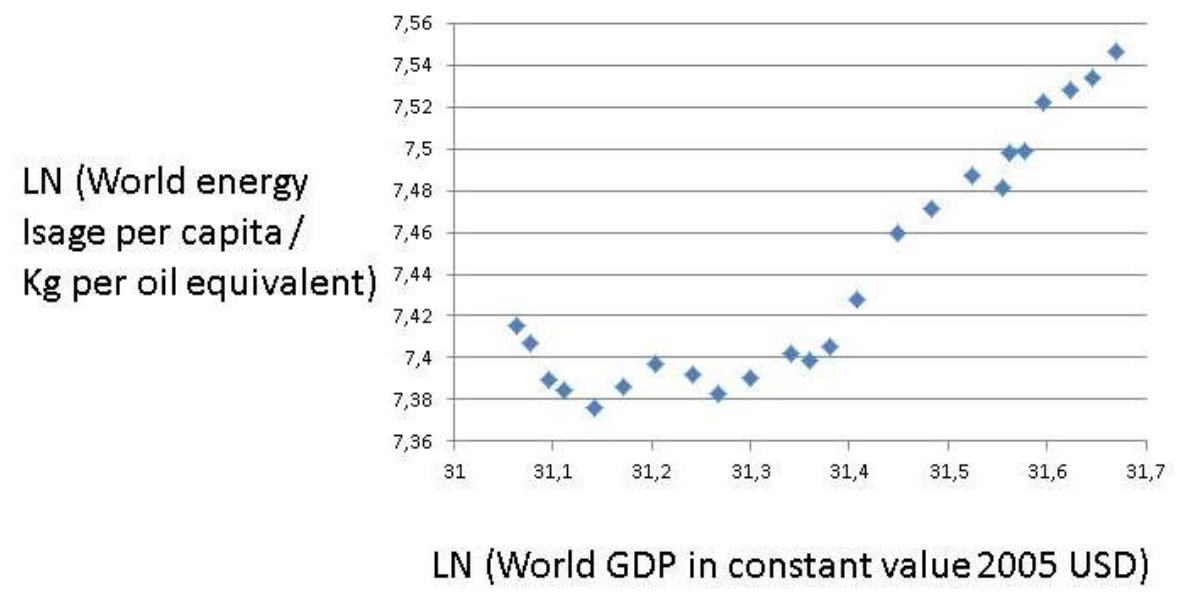

Figure 2. GDP and Energy per Person 1990-2014

Decarbonisation is the UNFCCC policy promise to undo these "dismal" links by making GDP and energy consumption rely upon carbon neutral energy resources, like modern renewables and atomic energy. Thus, the upward sloping curves must be reversed but still slope outward. Let us apply this model to three big countries along the new Silk Road, focussing upon affluence, energy, emissions and environment. 


\section{CO2-Temperature Rise}

One may attempt to calculate exactly how increases in greenhouse gases impact upon temperature augmentations. Take the case of $\mathrm{CO} 2 \mathrm{~s}$, where a mathematical formula is employed:

a) $\quad T=T c+T n$, where " $T$ " is temperature, " $T c$ " is the cumulative net contribution to temperature from $\mathrm{CO} 2$ and $\mathrm{Tn}$ the one. "CO2" refers to all $\mathrm{CO} 2$, there is no distinction between man-made and natural $\mathrm{CO} 2$.

But when it comes to methane, it is not known whether the tundra will melt and release enormous amounts. But methane does not stay in the atmosphere long, like CO2s. For the other greenhouse gases, there is no similar calculation as for the CO2s: If humans could eat less meat from cows, it would mean a great improvement, as more than a billion cows emit methane. Food from chicken should replace beef meat and burgers, and eating less meat should prevail. The general formula reads:

b) $\quad d T=\lambda * d F$, where "dT" is the change in the Earth's average surface temperature, " $\lambda$ " is the climate sensitivity, usually with degrees Celsius per Watts per square meter $\left({ }^{\circ} \mathrm{C} /[\mathrm{W} / \mathrm{m} 2]\right)$, and "dF" is the radiative forcing.

To get the calculations going, we start from lambda between 0.54 and 1.2, but let's take the average $=$ 0.87. Thus, we have the formula (Myhre et al., 1998):

$$
0.87 \times 5.35 \times \operatorname{Ln}(\mathrm{C} / 280)
$$

Figure 3 shows how $\mathrm{CO} 2$ emissions may raise temperature to 4-5 degrees, which would be Hawking's worst case scenario.

\section{CO2 atmospheric concentration vs. Rise in global temperature}

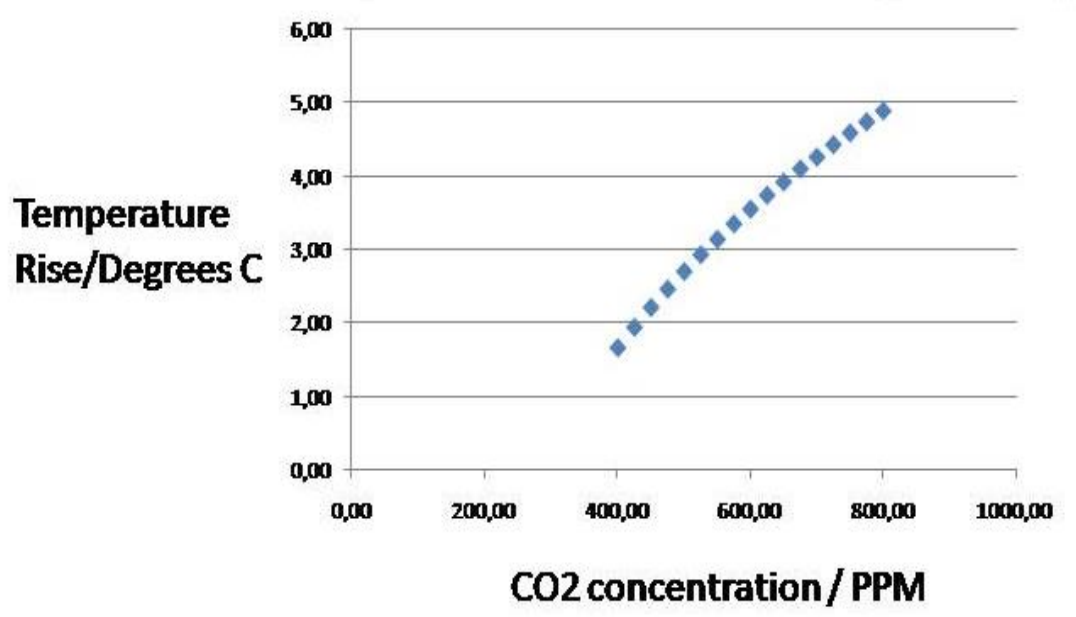

Figure 3. CO2s and Temperature Rise in CELCIUS

When taking into account that global planning speak of a 20-30 per cent increase in energy for the coming decades, and then one understands the warning of Hawking: This century may most likely be the greenhouse period of mankind, especially when one looks at the future energy projections (Figure 4). 


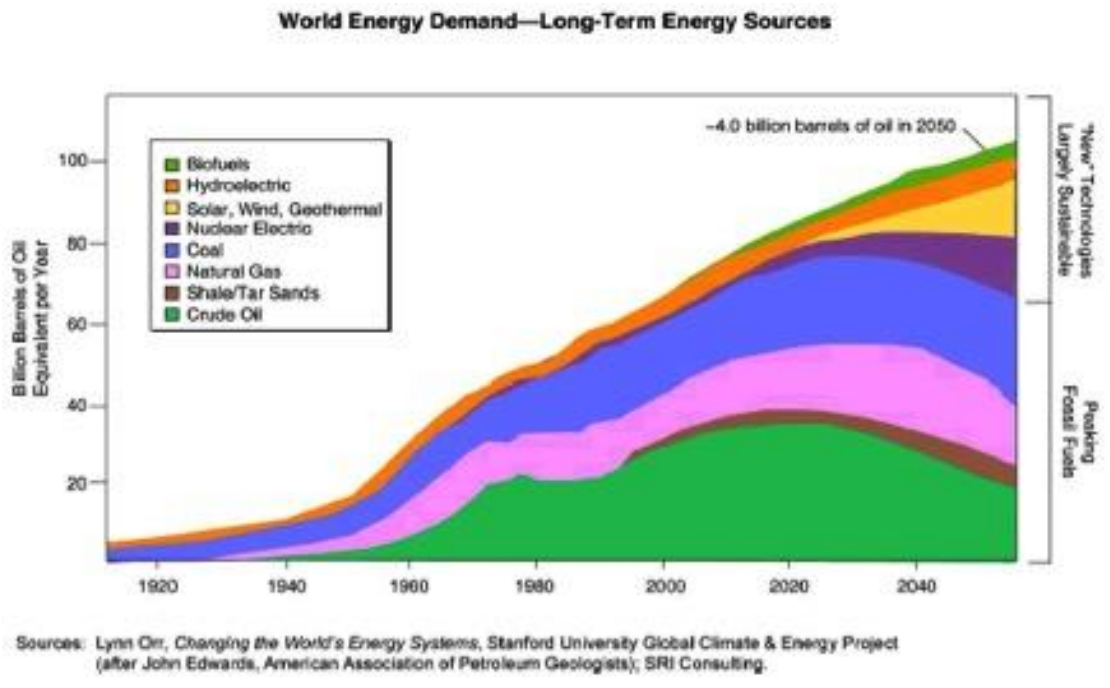

Figure 4. Standard Energy Consumption Projections

All this new energy must come from renewables, for example solar power parks.

\section{Catastophies}

Sooner or later as global warming continues, outcomes like the following arrive, here with a few examples of already occurring disasters:

a) Huge land losses along the costs (Bangladesh, Vietnam);

b) Too high temperatures for men and women to work outside with constant need of air conditioning increasing climate change (Middle East, South East Asia);

c) Food production decline (Africa);

d) Fish harvest decrease (Pacific Ocean, Atlantic, Indian Ocean);

e) Droughts and starvation (Africa);

f) Lack of fresh water supply (India, USA);

g) Drying up of rivers, affecting electricity supply (South America);

h) Ocean acidification and species extinction (everywhere);

i) Highly volatile climate with tremendous damages from flooding and storms or hurricanes and tornados (Pakistan, Sri Lanka, Bangladesh, Thailand, etc.);

j) Extremely violent forest fires (Portugal, Indonesia);

k) Transformations of warm and cold currents in the oceans (Gulf Stream, North Atlantic Current).

1) Great damage to the North and South Poles, Diminution of glaciers globally.

\section{Decarbonisation: COP21 GOAL II}

Consider now Table 1, using the giant solar power station in Morocco as the benchmark-How many would be needed to replace the energy cut in fossil fuels and maintain the same energy amount, for a few selected countries with big $\mathrm{CO} 2$ emissions? 
Table 1. Number of Ouarzazate Plants Necessary in 2030 for COP21's GOAL II: Global Scene

\begin{tabular}{llll} 
Nation & $\begin{array}{l}\text { Co2 reduction pledge/ } \\
\text { \% of 2005 emissions }\end{array}$ & $\begin{array}{l}\text { Number of gigantic solar } \\
\text { plants needed (Ouarzazate) }\end{array}$ & $\begin{array}{l}\text { Gigantic plants needed } \\
\text { for 40\% reduction }\end{array}$ \\
\hline United States & $26-28^{\text {(Note } 1)^{2}}$ & 2100 & 3200 \\
China & none ${ }^{(\text {Note } 2)}$ & 0 & 3300 \\
EU28 & $41-42$ & 2300 & 2300 \\
India & none ${ }^{\text {(Note 2) }}$ & 0 & 600 \\
Japan & 26 & 460 & 700 \\
Brazil & 43 & 180 & 170 \\
Indonesia & 29 & 120 & 170 \\
Canada & 30 & 230 & 300 \\
Mexico & 25 & 120 & 200 \\
Australia & $26-28$ & 130 & 190 \\
Russia & none ${ }^{\text {(Note 3) }}$ & 0 & 940 \\
World & N/A & N/A & 16000 \\
\hline
\end{tabular}

Note. Average of 250-300 days of sunshine used for all entries except Australia, Indonesia, and Mexico, where 300-350 was used.

If countries rely to some extent upon wind or geo-thermal power or atomic power, the number in Table 1 will be reduced. The key question is: Can so much solar power be constructed in some 10 years? If not, Hawkins may be right. Thus, the COP23 should decide to embark upon an energy transformation of this colossal size.

Solar power investments will have to take many things into account: energy mix, climate, access to land, energy storage facilities, etc. They are preferable to nuclear power, which pushes the pollution problem into the distant future with other kinds of dangers. Wind power is accused to being detrimental to bird life, like in Israel's Golan Heights. Geo-thermal power comes from volcanic power and sites. Let us look at the American scene in Table 2.

Table 2. Number of Ouarzazate Plants Necessary in 2030 for COP21's GOAL II: American Scene

\begin{tabular}{|c|c|c|c|}
\hline Nation & $\begin{array}{l}\text { Co2 reduction pledge/ } \\
\% \text { of } 2005 \text { emissions }\end{array}$ & $\begin{array}{l}\text { Number of gigantic solar } \\
\text { plants needed (Ouarzazate) }\end{array}$ & $\begin{array}{l}\text { Gigantic plants needed } \\
\text { for } 40 \% \text { reduction }\end{array}$ \\
\hline Canada & 30 & 230 & 300 \\
\hline Mexico & 25 & 120 & 200 \\
\hline Argentina & none ${ }^{\text {(Note 2) }}$ & 0 & 80 \\
\hline
\end{tabular}




\begin{tabular}{|c|c|c|c|}
\hline Peru & none ${ }^{\text {(Note 2) }}$ & 0 & 15 \\
\hline Uruguay & none ${ }^{\text {(Note 2) }}$ & 0 & 3 \\
\hline Chile & 35 & 25 & 30 \\
\hline
\end{tabular}

Note. Average of 250-300 days of sunshine per year was used for Canada, 300-350 for the others.

It has been researched has much a climate of Canadian type impacts upon solar power efficiency. In any case, Canada will need backs ups for its many solar power parks, like gas power stations. Mexico has a very favourable situation for solar power, but will need financing from the Super Fund, promised in COP21 Treaty. In Latin America, solar power is the future, especially as water shortages may be expected. Chile can manage their quota, but Argentine needs the Super Fund for sure. Table 3 has the data for the African scene with a few key countries, poor or medium income.

Table 3. Number of Ouarzazate Plants Necessary in 2030 for COP21's GOAL II: African Scene

\begin{tabular}{|c|c|c|c|}
\hline Nation & $\begin{array}{l}\text { Co2 reduction pledge/ } \\
\% \text { of } 2005 \text { emissions }\end{array}$ & $\begin{array}{l}\text { Number of gigantic solar } \\
\text { plants needed (Ouarzazate) }\end{array}$ & $\begin{array}{l}\text { Gigantic plants needed } \\
\text { for } 40 \% \text { reduction }\end{array}$ \\
\hline Algeria & $7-22^{\text {(Note 4) }}$ & 8 & 50 \\
\hline Egypt & none ${ }^{\text {(Note 2) }}$ & 0 & 80 \\
\hline Senegal & $5-21$ & 0,3 & 3 \\
\hline Ivory Coast & $28-36^{\text {(Note 4) }}$ & 2 & 3 \\
\hline Ghana & $15-45^{\text {(Note 4) }}$ & 1 & 3 \\
\hline Angola & $35-50^{\text {(Note } 4)}$ & 6 & 7 \\
\hline Kenya & $30^{\text {(Note 4) }}$ & 3 & 4 \\
\hline Botswana & $17^{\text {(Note 4) }}$ & 1 & 2 \\
\hline Zambia & $25-47^{\text {(Note } 4)}$ & 0,7 & 1 \\
\hline South Africa & none (Note 2) $^{(1)}$ & 0 & 190 \\
\hline
\end{tabular}

Note. Average of 300-350 days of sunshine per year was used.

Since Africa is poor, it does not use much energy like fossil fuels, except Maghreb as well as Egypt plus much polluting South Africa, which countries must make the energy transition as quickly as possible. The rest of Africa uses either wood coal, leading to deforestation, or water power. They can increase solar power without problems when helped financially.

Table 4 shows the number of huge solar parks necessary for a few Asian countries. The numbers are staggering, but can be fulfilled, if turned into the number ONE priority. Some of the poor nations need external financing and technical assistance. 
Table 4. Number of Ouarzazate Plants Necessary in 2030 for COP21's GOAL II: Asian Scene

\begin{tabular}{llll} 
Nation & $\begin{array}{l}\text { Co2 reduction pledge/ } \\
\text { \% of 2005 emissions }\end{array}$ & $\begin{array}{l}\text { Number of gigantic solar } \\
\text { plants needed (Ouarzazate) }\end{array}$ & $\begin{array}{l}\text { Gigantic plants needed } \\
\text { for 40\% reduction }\end{array}$ \\
\hline Saudi Arabia & none ${ }^{(\text {Note } 2)}$ & 0 & 150 \\
Iran & $4-12^{\text {(Note } 4)}$ & 22 & 220 \\
Kazakhstan & none ${ }^{(\text {Note } 2)}$ & 0 & 100 \\
Turkey & 21 & 60 & 120 \\
Thailand & $20-25^{(\text {Note } 4)}$ & 50 & 110 \\
Malaysia & none ${ }^{(\text {Note } 2)}$ & 0 & 80 \\
Pakistan & none ${ }^{(\text {Note } 2)}$ & 0 & 60 \\
Bangladesh & 3,45 & 2 & 18 \\
\hline
\end{tabular}

Note. Average of 250-300 days of sunshine was used for Kazakhstan, 300-350 days of sunshine per year for the others.

Finally, we come to the European scene, where also great investments are needed, especially as nuclear power is reduced significantly and electrical cars will replace petrol ones, to a large extent.

Table 5. Number of Ouarzazate Plants Necessary in 2030 for COP21's GOAL II: European Scene

\begin{tabular}{llll} 
Nation & $\begin{array}{l}\text { Co2 reduction pledge/ } \\
\text { \% of 2005 emissions }\end{array}$ & $\begin{array}{l}\text { Number of gigantic solar plants } \\
\text { needed (Ouarzazate) }\end{array}$ & $\begin{array}{l}\text { Gigantic plants needed } \\
\text { for 40\% reduction }\end{array}$ \\
\hline Germany & $49^{\text {(Note 5) }}$ & 550 & 450 \\
France & $37^{\text {(Note 5) }}$ & 210 & 220 \\
Italy & $35^{\text {(Note 5) }}$ & 230 & 270 \\
Sweden & $42^{\text {(Note 5) }}$ & 30 & 30 \\
\hline
\end{tabular}

Note. Average of 250-300 days of sunshine per year was used.

The future energy transformation will be the largest management tasks mankind has undertaken. It must succeed, in order to avoid Hawking's dire warming. Above calculation is merely an example of its immensity to save humanity. Solar plants can be replaced often by solar facilities on roofs.

\section{Conclusion}

The COP Framework with its Treaty from Paris 2015 amounts to a global Common Pool Regime (CPR), but it is far weaker than Ostrom (1990) predicted, as gaming by the governments of the world could destroy it (Stern, 2007, 2015; Sachs, 2015; Conca, 2015; Vogler, 2016; Dutta, 1999). 


\section{Sources}

BP Energy Outlook. (2016).

British Petroleum Statistical Review of World Energy. (2016).

CO2 Emission Reduction With Solar. (n.d.). Retrieved from http://www.solarmango.com/in/tools/solar-carbon-emission-reduction

Energy Information Administration. (n.d.). Washington, DC.

EU Emissions Database for Global Research EDGAR. (n.d.). Retrieved from http://www.edgar.jrc.ec.europa.eu/

EU Joint Research Centre Emission Database for Global Atmospheric Research. (n.d.). Retrieved from http://www.http://edgar.jrc.ec.europa.eu/overview.php

European Commission, Joint Research Centre (JRC)/PBL Netherlands Environmental Assessment Agency. Emission Database for Global Atmospheric Research (EDGAR). (n.d.). Retrieved from http://www.edgar.jrc.ec.europe.eu

International Energy Agency. (n.d.). Paris.

OECD National Accounts data files. (n.d.).

Paris 2015: Tracking country climate pledges. (2015). Carbon Brief. Retrieved from https://www.carbonbrief.org/paris-2015-tracking-country-climate-pledges

UN Framework Convention on Climate Change. (n.d.). Retrieved from http://www.unfccc.int/ghg_data/ghg_data_unfccc/time_series_annex_i/items/3814.php

World Bank Data Indicators. (n.d.). Retrieved from http://www.data.worldbank.org

World Bank national accounts data. (n.d.). Retrieved from http://www.data.worldbank.org

World Resources Institute CAIT Climate Data Explorer. (n.d.). Retrieved from http://www.cait.wri.org

\section{References}

Conka, K. (2015). Un Unfinished Foundation. The United Nations and Global Environmental Governance. Oxford: OUP.

Dutta, P. L. (1999). Strategies and games. Cambridge, MA: MIT Press.

Kaya, Y., \& Yokoburi, K. (1997). Environment, energy, and economy: Strategies for sustainability. Tokyo: United Nations University Press.

Myhre, G., Highwood, E. J., Shine, K. P., \& Stordal, F. (1998). New estimates of radiative forcing due to well mixed greenhouse gases. Geophysics Research Letters, 25(14), 2715-2718.

Ostrom, E. (1990). Governing the Commons. Cambridge: CUP.

Sachs, J. D. (2015). The Age of Sustainable Development. New York: Columbia University Press.

Stern, N. (2007). The Economics of Climate Change. Oxford: OUP.

Stern, N. (2015). What are we waiting for? Cambridge, MA: MIT Press.

Vogler, J. (2016). Climate Change in World Politics. Basingstoke: Macmillan Palgrave. 